\title{
'It's not fair': maize, money, and moral economies in the Southern Highlands of Tanzania
}

\author{
Natasha Watts ${ }^{1}$ \\ University of Cambridge, UK
}

\begin{abstract}
Over the past decade there has been increased emphasis on agricultural development in Africa to meet a nexus of challenges including global food security, national and local economic growth and employment creation, energy security, and the search for new profit frontiers. This is occurring at a time of decreasing public funding for agricultural development, and a deeper focus on the potentially speculative and predatory nature of financial models in the wake of the financial crisis in the late 2000s. One outcome has been the development of innovative financing mechanisms. An example is social impact investing (SII), which aims to generate financial returns and positive social impacts for intended beneficiaries. In this article, I examine an SII programme in the Tanzanian agricultural sector. I unpack what happens when its vision of 'ethical capitalism' is implemented in the context of farmer livelihoods and moral economies, especially at a time of environmental disruption. In doing so, I argue for the continuing relevance of studying moral economies within political ecology.
\end{abstract}

Key words: Tanzania, agriculture, social impact investing, moral economy

\section{Résumé}

Au cours de la dernière décennie, l'accent a été mis sur le développement agricole en Afrique pour relever les défis suivants: sécurité alimentaire mondiale, croissance économique nationale et locale, création d'emplois, sécurité énergétique et recherche de nouvelles frontières du profit. Cela se produit à un moment où les financements publics diminuent pour le développement agricole et, à la suite de la crise financière de la fin des années 2000, on se concentre davantage sur des modèles financiers potentiellement spéculatifs et prédateurs. Un résultat a été le développement de mécanismes de financement innovants. Un exemple est linvestissement à impact social (SII), qui vise à générer des rendements financiers et des impacts sociaux positifs pour les bénéficiaires visés. Dans cet article, j'examine un programme SII dans le secteur agricole tanzanien. Je dévoile ce qui se passe lorsque sa vision du «capitalisme éthique» est mise en œuvre dans le contexte des moyens de subsistance des agriculteurs et des économies morales, en particulier à une époque de perturbation de l'environnement. Ce faisant, je plaide pour la pertinence continue de l'étude des économies morales dans l'écologie politique.

Mots clés: Tanzanie, agriculture, investissement à impact social, économie morale

\section{Resumen}

Durante la década pasada ha habido un aumento del énfasis con respecto al desarrollo agrícola en África con el fin de enfrentar un entramado de retos que incluyen: seguridad alimentaria global, crecimiento económico nacional y local y creación de empleos, seguridad energética, y la búsqueda de nuevas fronteras de ingresos. Esto sucede en tiempos de una reducción de fondos públicos para el desarrollo agrícola, y una mayor atención en la potencialmente especulativa y depredadora naturaleza de los modelos financieros tras la crisis económica de los últimos años de la década del 2000. Un efecto ha sido el desarrollo de innovadores mecanismos financieros. Un ejemplo es la inversión con impacto social (SII), que apunta a la generación de rendimientos financieros e impactos sociales positivos para los beneficiarios previstos. En este artículo examino un programa SII en el sector agrícola de Tanzania. Desentraño lo que sucede cuando esta visión de "capitalismo ético" es implementada en el contexto de medios de subsistencia de agricultores y economías morales, especialmente en

\footnotetext{
${ }^{1}$ Dr. Natasha Watts, Department of Geography, University of Cambridge, UK. Email: natashawatts "at" live.com. Research was supported by an Economic and Social Research Council Studentship (Award KFW/301419246).
} 
tiempos de disrupción ambiental. De esta manera, discuto la constante pertinencia del estudio de economías morales dentro de la ecología política.

Palabras clave: Tanzania, agricultura, inversión de impacto social, economía moral

\section{Introduction}

The past two decades have seen increasingly urgent calls to boost agricultural production in Africa in response to the 'perfect storm' of urbanisation, meatification of diets, increasing pressures on land and water resources, and climate change (Conway 1997; Godfray et al. 2010). Mirroring broader processes in development, there has been a noticeable shift in agricultural development narratives and practice towards deeper penetration of financial motives, models, and actors. This has occurred in terms of direct land acquisitions, filling gaps in agricultural value chains, and in financing partnerships and channels (Brooks 2016; Clapp 2014, 2012; Ghosh 2010; Isakson 2014; Ouma 2016; Russi 2013). Some financial actors aim to not only produce a financial return, but one that is directly correlated with positive developmental social impacts through so-called 'social impact investing' (SII) (Brest and Born 2013; Bugg-Levine and Emerson 2011; O'Donohoe et al. 2010). The underlying assumption is that not only does the implementation of financial models have the potential to promote agricultural development and alleviate poverty at scale, but it provides a lucrative business opportunity for investors. Through SII, therefore, investors are attempting to build their vision of a more ethical capitalism in the agricultural sector.

SII is occurring at a range of scales carried out by a variety of actors, from commercial banks and private equity houses, to international development donors and foundations, and the emergence of smaller-scale and project-specific organisations. It is operating on a spectrum from philanthropic capital to returns driven capital, and through a variety of forms. These diverse operations all aim (at least in principle) to tread firmly across divides between charity and commerce, the socio-environmental and the economic, and the roles of state, market, and civil society.

In light of the proliferation of SII, it is pertinent to ask whether projects that explicitly intend to produce directly correlated positive social and financial impacts are any more successful in being adaptive and responsive to local knowledge systems, valuations, and livelihoods than previous development initiatives. In other words, how do abstract financial models map onto the messy realities of agricultural livelihoods, and how flexibly do they take into account local knowledge systems, livelihoods, and valuations in their pursuit of social and financial impacts? These questions of winners and losers and access to resources are of central interest to political ecologists. While there is much corporate literature surrounding SII, however, analysis of empirical evidence on SII projects is hard to find.

In this article, I explore a case study of a for-profit agricultural input loan scheme for smallholder farmers in the Lower Kilolo District of Tanzania that is run by an American social impact investment organisation with a portfolio of Tanzanian registered businesses. To adhere to confidentiality agreements, in this article I will refer to the organisation using the pseudonym 'Panther Progress', or 'Panther.' In Panther's programme, hybrid seed and synthetic fertilizer for maize production are provided on credit, and the loan is repaid in maize after the harvest in order to turn 'crops to cash'. After three years of reported success, when field teams visited villages to collect maize loan repayments in 2015 they found that many farmers failed to repay their loans by the deadline. While there may be a proportion of defaulting farmers who did refuse to repay out of wilful disobedience, evidence suggests that the picture is more complex, and a focus on farmer moral economic principles is useful.

Drawing on 9 months of qualitative fieldwork (farmer interviews, participatory methods, focus groups, participant observation, key informant interviews) conducted in 2015-2016 with both smallholder farmers and Panther Progress staff from across the organisation in Tanzania and in the US, I unpack what happened in Lower Kilolo in 2015. Firstly, I introduce the theoretical framework and discuss the relevance of studying moral economies with political ecology. The article then explores what happens when the Panther model met farmer realities in the context of environmental disruptions, focusing on the disjuncture between visions of ethical capitalism and farmer moral economies. I argue that despite its professed aims to generate social as well as 
financial impacts, the Panther Progress model also suffers from many of the problems of past top-down development initiatives - for example projects of the first Green Revolution - that employ externally constructed, inflexible, and technocratic solutions to increasing the productivity of smallholder farmers. This article highlights three interlinked areas in which, in the context of environmental disruptions, the Panther Progress model clashed with risk-averse and flexible smallholder farming in Lower Kilolo. I conclude that although in times of good harvest the Panther model worked well, its collapse when faced with environmental disruptions exposed fundamental incompatibilities between the financial model and farmer moral economies and demonstrated the challenge of imposing a rigid financial model onto complex and flexible rural realities.

\section{Political ecology engagement with studying moral economies}

A political ecology lens is a useful vantage point from which to examine how SII meets the realities of agricultural livelihoods in the Global South. Political ecology has a long history of unpacking the imposition of development initiatives and discourses, how they interact with social, cultural, political, economic, and environmental realties, and how environmental degradation, marginalisation, and hunger can result from the so-called 'pursuit of progress' carried out in the name of both the state and the market (Adams 2003; Fairhead and Leach 1996; Peet and Watts 1996; Rocheleau et al. 2001; Scott 1998; Shiva 1992; Watts 1983). Research has examined the agency of local people, and their adapted and risk-averse indigenous knowledge systems and livelihood 'bricolage', in efforts to push back against the imposition of these externally constructed development models and discourses (Agrawal 1995; Chambers 1983; Mazur and Titilola 1992; Mortimore 1998; Richards 1985; Scott 1987; Sillitoe 2007).

During the 1970s and 1980s scholars unpacked the internal processes and relations of agrarian communities through the concept of 'moral economies.' The study of moral economies can be defined as examining the ways in which economic activity is influenced by moral-political norms and sentiments: 'who is morally bound to whom, and why' (Shipton 2010). Gotz (2015) discusses how the concept of a 'moral economy' emerged in the eighteenth century in tandem with the development of classical political economy, which detached considerations of morality from understandings of the economy by elevating productivity, growth, and self-interest as drivers of economic decision-making. A concerted effort to study moral economies occurred during the 1970s by Thompson (1971) and - importantly for political ecologists - Scott (1976), who exported the concept to the Global South in The moral economy of the peasant: rebellion and subsistence in Southeast Asia, and Watts (1983) in Silent violence: food, famine, and peasantry in Northern Nigeria. The concept of the 'moral economy' has been described as a 'beautiful example of transdisciplinary migration' as it has been employed in various ways by historians, political scientists, anthropologists, and geographers (Fassin 2009, quoted in Edelman 2012: 59).

For Thompson (1971), the moral economy is associated with 'confrontations in the marketplace', specifically between the norms, customary rights, and utopian aspirations embedded in pre-capitalist societies, and the encroaching capitalist principles as expressed, for instance, in eighteenth century English food riots over just prices for staple produce. Scott (1976) shifted the emphasis on to producers rather than consumers, and encouraged deeper attention towards values. He outlined the moral economy of the peasant and its nonprofit maximising subsistence ethic, as well as the tendency towards risk-aversion that is often taken for backwardness and irrationality. Scott goes further than Chayanov in his discussion of smallholder farmer obligations by taking into account not just the family unit, but also other social relations, for example villagebased mutual support in times of poor harvest or environmental disruptions (see Edelman 2005 for a review). The culture of redistributive obligation embedded in the moral economy of the peasant is, for Scott, in contrast to the neoclassical political economy model based on rational household decision-making and profitmaximisation. Watts (1983) furthered this analysis by focusing on the socio-historical factors shaping knowledges, practices, and politics. Peasants were not vulnerable to drought due to inherent irrationality and ignorance, but due to the articulation of otherwise well-adapted communities within colonial capitalist relations, and then within development as modernisation narratives and policies. From this perspective, "the tissues of the moral economy were stripped away, making peasants vulnerable to both market crises and a capricious climate" 
(Watts 1983: xxi). For Thompson, Scott, and Watts, individual and collective action is prompted when this moral economy is threatened.

More recently, scholars have worked to reinvigorate the study of moral economies to demonstrate its continuing relevance. These scholars go beyond simplistic assumptions of the 'moral economy' as something that existed in pre-capitalist societies and is eroded by the penetration of capitalism (see Booth 1994 for critique of early moral economy analyses; Edelman 2005; Ogawa 2006; Sayer 2000; Sayer 2001). Sayer (2000) highlights that examining moral economies forms an important analytical mode of investigation, rather than simply drawing normative statements about particular social relations in history. Moral economies are the "expression of and production of a social group's explicitly normative frameworks outlining the 'proper' organization of society and division of (what are perceived to be) scarce resources" (Wolford 2005: 245). Analysing moral economies encourages us to examine the means and ends of economic activity, subjective claims to objective resources (Wolford 2005); norms surrounding entitlements and how these link to capabilities (the power and ability to do something) (Sen 1982); how assemblages of norms and behaviours may clash; and power relations that dictate the outcomes of these clashes. According to Sayer (2000), a sensitivity to moral economies invites us to ask important questions like what economic activities are for, how responsibilities are allocated, what things can be commodified, and how people behave when their moral economy is disrupted or threatened. While these renewed debates have mostly been siloed within cultural political economy, they provide useful perspectives for political ecology analyses.

A consideration of moral economies is particularly relevant when dealing with agrarian relations of investment and debt, as I do in this article. While debt is typically understood as a financial interaction, it is also fundamentally a socially and historically situated moral relationship (Dodd 2014; Graeber 2014). Debt can therefore be understood as a contradiction between and within moral economies and forms of 'ethical capitalism.' In some cases, debt is 'socially sanctioned', such as in pension fund investment, while in other cases, for example an individual defaulting on a mortgage repayment, it is "a perversion or deviation in human relations - an abnormal situation that needs to be rectified" (Roitman 2003: 212). The moral relationship of debt has a distinct temporality both in terms of the timeframe of repayment, but also in foreclosure of the future, as default often acts as a form of 'moral downgrading' that limits the debtor's chances of accessing future loans (Fourcade et al. 2013). In this way, "debt both supports and is reinforced by a moral economy that is often used to justify the social, economic, and political asymmetries of power that exist between creditors and debtors" (Dodd 2014: 136). Moral dilemmas surrounding debt have led to certain forms - for example usury - being forbidden in particular places, times, and societies (Shipton 2010).

In this article, I unpack the moral economies of smallholder farmers in the Southern Highlands of Tanzania and examine what happens when they interact with the particular vision of 'ethical capitalism' implemented by an agricultural SII organisation that itself relies on moralistic assumptions of what constitutes ethical socio-economic relations. Focusing on moral economies adds another dimension to understanding the clashes between farmer livelihoods and the SII loan programme beyond questions of poverty and differential access to resources. The outcomes demonstrate that what can be considered ethical socio-economic relations are fundamentally context specific.

\section{Panther Progress}

Panther Progress is an American SII organisation that was founded by a serial entrepreneur who, in the wake of the financial crisis in the late 2000s, thought it was time to 'stop making rich people richer and start making poor people richer.' Rather than relying solely on aid and donations, Panther is also financed by impact investors who expect - at some point in the future and to a greater or lesser extent - a financial return on their investment as well as evidence of positive social impact for smallholder farmers. For the Panther management team, the profit-motive is crucial at every stage of the operation as "it just becomes a simple question of what is the social return of all these aid dollars that flow into Africa. If you come from the investment world you know the power of capital and what equity concentrated on a problem can do." 
According to Panther, a 'lack of economy' is at the heart of the challenge of boosting smallholder agricultural production. They see agricultural value chains in Iringa Region as 'broken', as on the one hand smallholder farmers are often unable to access high quality agricultural inputs, and on the other hand market buyers struggle to locally procure enough produce to reach capacity. According to one staff member, "if you take this vast pool of what we call 'hands and lands' - the farmer - and you put it together with the fact that we have got to find a lot more food in the world, that becomes a tremendous business opportunity." For Panther, filling these gaps in agricultural value chains presents not only the chance of achieving wide ranging social impact, but it also presents a huge business opportunity.

The solution that Panther forwards is the provision of agricultural inputs (hybrid seed and synthetic fertilizer) on credit to farmers. The provision of loans in-kind rather than in cash is partly in response to the low availability and high costs of these quality inputs, but it is also based on a lack of trust in farmers to use the loan in the way in which it is intended. In order to join the programme, farmers have to provide two bags of maize of at least $100 \mathrm{~kg}$ each and complete a credit assessment form that details their experience with hybrid seed and synthetic fertilizers, as well as what possessions they can put up as collateral. Panther does not give the loan capital through which the inputs are bought themselves, but instead arranges for a commercial bank to provide it by putting up the necessary collateral. Through this collateral, Panther is in effect acting as a guarantor for the farmers to make them 'creditworthy' and 'investable.' Farmers are organized into small teams that are registered, for a small fee, with the government as cooperatives or limited companies. Panther also provides agronomic training to farmers to ensure that they reach the productivity potential of the inputs. Participating farmers repay the loans in maize after the harvest the following year, and Panther builds partnerships with market buyers for this aggregated produce. Once the maize has been sold, any profit after Panther has taken their $15 \%$ cut is then delivered to the farmers' bank accounts. Panther estimates that through the provision of high quality inputs and agronomic training harvests should increase eight-fold, enabling farmers to meet their food needs, repay the loan in produce to Panther, and make a profit on any surplus.

For Panther, this programme intends to build a more ethical capitalism in the Tanzanian agricultural sector in a variety of ways. Firstly, it provides farmers with access to high quality agricultural inputs that are affordable on credit. It also works to expand formal financial inclusion to smallholder farmers by entrenching financial discipline and building their credit rating to render then 'investable.' Finally, the organisation provides a guaranteed and reliable market for farmers' produce at a good price. In practice, however, for many farmers in Lower Kilolo District in 2014-2015, their experiences of programme participation were far from ethical or beneficial.

\section{Maize, money, and moral economies in Lower Kilolo}

Lower Kilolo District is located in the northeast of Iringa Region in the Southern Highlands of Tanzania. It is one of the 'big five' regions in terms of agricultural production and, alongside Mbeya, Njombe, Rukwa, and Ruvuma, is considered to be at the heart of the Southern Highlands 'breadbasket' that is responsible for $46 \%$ of national maize production, and almost $90 \%$ of maize procured by the National Food Reserve Agency (Bisanda et al. 1998). Agriculture accounts for $85 \%$ of the region's GDP, and over $80 \%$ of cultivation is carried out by smallholder farmers with less than 10 hectares of land (Sarris and Morrison 2010; URT 2016).

Maize is at the centre of socio-cultural, spiritual, and economic life in Lower Kilolo. There are multiple demands on farmers' harvests, and maize becomes enrolled in different and sometimes conflicting spheres of value. The primary aim of maize cultivation is to meet household subsistence needs, and this is in contrast to other crops that are primarily designated for business: "in our culture we always cultivate the food crops like maize and some cash crops like tomatoes", one farmer said. The maize cobs are harvested, husked, and threshed to create white maize flour that is used to make ugali, which has the consistency of firm polenta. Usually ugali is made with the more nutritious and less labor-intensive wholemeal dona maize flour rather than the highly refined sembe flour that is more popular in urban areas. Ugali is typically eaten with maharage (beans), mboga (vegetables), nyanya (tomatoes), and nyama (meat) when it is available. It is eaten daily, and often more than once. When I asked farmers why so many people grew maize I was told that it was because people want to eat ugali. In Iringa Region chakula (food) is closely associated with ugali, and the sharing of ugali with visitors, 
friends, neighbours, and family is a crucial element of local culture. When arriving at a house in Lower Kilolo it is common to be greeted with calls of karibu kwa chakula (welcome for food) or apologies that the ugali is not yet ready. The ubiquity of ugali means that it is sometimes used to make tribal distinctions, both seriously and in jest, for example 'you eat ugali like a Hehe!' (Ohna et al. 2012: 9).

As well as playing a central socio-cultural role in life in Lower Kilolo, maize is also extremely important in terms of its carbohydrate and protein contributions to rural diets. Maize makes significant carbohydrate (66.8\%-69.5\%) and protein (83\%-90\%) contributions to rural diets in the Southern Highlands (Mboya et al. 2011). It is also a good source of phosphorous, as well as containing small amounts of calcium, iron, thiamine, and niacin (Mboya et al. 2011).

Despite its importance for household subsistence, maize is also called upon in other ways, and is enrolled into sometimes competing spheres of value. Maize, for example, plays an extremely important role in spiritual relations for multiple denominations of Christianity and Islam. These religions may differ in their beliefs and customs, but they both require followers kutoa sadaka (to make offerings), and there are powerful narratives of meaning and responsibility attached to the things offered. One of the most important offerings is that given after the harvest. All the religions require followers to give an offering of $10 \%$ of their harvest, for example if they harvest 10 gunia (bags) of maize, they have to offer one, and if they harvest 100 gunia they have to give 10. While this offering in produce is common across all religions, the degree of necessity and meaning attached to provision of the offering does vary. A Lutheran priest clarified that "if you have something you pay, if you don't then you do not." The situation is, however, quite different for followers of the Tanzanian Assemblies of God. What sets this church apart from the others is the extent of the fear surrounding non-payment of the sadaka. A woman in Lundamatwe provided an example of a farmer in a nearby village whose maize plants allegedly grew without maize cobs. This was attributed to the fact that he had not given an offering the year before. A preacher in Vitono told me that if people do not pay they are "cursed", and this 'curse' can take many forms:

If God blessed them to harvest, they should give back so that they can get out of the curses and get the blessings. The curses can come in the form of diseases, getting disturbed by spirits, waking up tired all the time, failing to work hence continuing being poor, or sometimes working really hard but not getting anything because there are no blessings in the work done.

In practice these offerings are used to pay for 'church business' such as hosting guests and buying supplies, but they play a parallel role in the lives of religious followers in the village. Material expressions of spiritual transactions are not simply one way. When someone gives an offering they expect something in return, for example bountiful harvests, health for the family, or good fortune in education or business. Offerings simultaneously represent paying back the everlasting debt of mankind to God, maintaining a relationship with the spiritual world, and asking for blessings of health, wealth, and prosperity. While something tangible is expected in return for the offering, its exact form and timing is less certain. In the case of the obligation of offerings, therefore, the value of maize is in its ability, through kuweka maombi (placing prayers), to form a tangible bridge to the transcendental world as a vehicle for hopes and fears to sustain crucial religious relationships that, for many, provide a roadmap for rural life.

Alongside subsistence and offerings to the church, maize plays a central role in budgeting for the following year's cultivation, which includes selecting seeds for planting and selling some to obtain money for renting labor, land, and equipment, as well as buying other inputs like fertilizer and hybrid seed. Families with school age children tended to prioritize selling maize to cover the cost of ada (school fees, including the cost of uniform and equipment). Furthermore, parents with children away at boarding school are required to send maize to the school as a contribution for their child's food: "This season I got 15 sacks of maize. 2 sacks of maize are for church offerings and the rest I keep for food... but also I give some of the maize for my son's food in school." Finally, farmers often keep an amount of maize as savings in the case of unforeseen events, investments, and emergencies during the year, or simply to wait until the market price improves: "...first I put 
some for food and give offerings to the church. Then I sell some amount of maize to pay school fees, and the remaining is for savings."

It is only after all these other uses and valuations that maize is seen by farmers as a crop for commercial sale. In this way, farmers in Lower Kilolo fit the classic description of smallholder farmers as risk-averse and partially engaged in input and output markets (Ellis 1993; Netting 1993). Apart from those participating in a programme such as that run by Panther, farmers usually sell their produce either opportunistically by the roadside or to dalali (traders who go from door-to-door buying produce). To try to get a better price, some farmers with access to transport such as a pikipiki (motorbike) or a bicycle instead take their produce directly to market buyers or private individuals near to Iringa town.

Another key characteristic of agriculture in Lower Kilolo is climatic variability, and in 2014-2015 environmental disruptions played a key role in mediating the relationship between participating farmers and Panther.

\section{Environmental disruptions in Lower Kilolo in 2015}

There is a noticeable correlation between farmers' perception of the success of the Panther programme, rainfall, and harvest size in Lower Kilolo. For example, one farmer explained that "...in the first year [20132014] we had a good experience with Panther because they gave us loans and it was a good season with lots of rains and we harvested well, but since the next year the harvests were small and we couldn't pay back the loans so our experience was not that good." In general, farmers deemed the early years of Panther participation to be a success, and this period corresponds with reports of relatively good rainfall in the 2012-2013 and 2013-2014 seasons. This is in contrast to the 2014-2015 season in which farmers experienced low and unreliable rainfall contributing to small harvest sizes, and in parallel they faced multiple challenges in negotiating their relationship with Panther.

Rainfall data recorded daily at a commercial dairy farm in Kilolo District supports the farmers' assessment that 2012-2013 and 2013-2014 were years of plentiful rainfall. In 2014-2015, however, the farm received 590mm of rainfall. This is below the average for the 28 years on record, but it by no means the lowest. The previous two years of good rains, however, may partly explain why this year stands out as one of particularly poor weather in recent memory, as one farmer explained: "this year there has not been enough rain. In the last 3 years the weather has been very changeable. The year before last the maize was good, but last year there was little rain so the maize grew short." It is not just overall rainfall quantity and inter-annual variability that posed a challenge for farmers in the 2014-2015 season, but also variability during the rainy season. In 20142015 the rainfall was intermittent, which caused problems as: "after a long time it rained, and after it started raining we planted the crops and then they germinated. After germination there was a period of intense sunshine, like a period of one month, then it started raining again very heavily for a short time, but by this time the crops were already destroyed. So, it didn't help with anything at all with the crops we planted first." Variability was therefore important both in the timing of the onset of the rains, and its intensity over time.

In Uhambingeto Ward of Kilolo District, the low rainfall in 2014-2015 had an unexpected consequence that devastated the harvest: a rat infestation. Farmers reported that: "rats have been a very big problem. They are the ones who brought a big problem even with Panther. The rats were too many that they were uncontrollable." Rats (Mastomys natalensis) are significant pests for cereal farming in Tanzania, and they are notoriously difficult to manage due to their capacity to adapt (Leirs et al. 1996; Leirs et al. 1990; Makundi et al. 2005; Makundi et al. 2006). Research has shown that rat populations in East Africa tend to oscillate in tandem with rainfall, with higher rainfall boosting the rats' food supply of seeds, foliage, roots, and insects, leading to higher breeding rates and population explosions (Leirs et al. 1990; Massawe et al. 2011). This is interesting in the context of Uhambingeto Ward where farmers reported a rat infestation in a year of lower than average rainfall. The clue to understanding this phenomenon is in the reports that the rats would 'come down from the hills' into the farms. This suggests that the infestation was more likely due to a rat population that had been steadily expanding during years of abundant rainfall facing limited food supplies on the hills in 2014-2015 due to lower rainfall. This meant that they were forced to come down the slopes into the farms to find food. The 
low rainfall also minimized the effectiveness of the local rat control technique of digging holes in the fields, by failing to fill them with water that would drown the rats as they tried to enter the farms.

These environmental disruptions changed the 'rules of the game' when Panther began to collect loan repayments in maize in the summer of 2015. While the lower rainfall and rat infestation do not explain why the programme collapsed in 2015, the resulting smaller than average harvests do suggest why rifts and contradictions were revealed at this time, in comparison to the previous years in which farmers reported that the weather had been favourable. The article will now proceed to unpack some of the resulting contradictions over the use and valuation of the maize crop, and temporal and material flexibility in loan repayment.

\section{Clashes between Panther and participating farmers}

The CEO and Founder of Panther believes that a major problem with many standard microfinance projects is that "they can't succeed because the farmer can't grow more than they can eat, so you are asking them to make a decision between selling you the food they would live on or dying. How can you expect them to make that decision?" After the poor harvest of 2015, however, many farmers participating in the Panther programme in Lower Kilolo were put in a position where they faced a serious question over how they prioritized uses for their maize harvest.

From the discussion so far, it is clear that for farmers in Lower Kilolo maize can be enrolled into diverse spheres of value; maize as a commodity for sale is only one part of this picture. This is in stark contrast to the Panther model that prioritizes maize as a crop produced for commercial sale. As a result, a major problem occurred when Panther attempted to collect repayment in maize in 2015 in the context of smaller than average harvests relating to environmental disruptions. A farmer in Vitono explained that to feed his household of 8 people, with a small buffer in case of emergencies, he needs 10 gunia of maize for the year. In 2015, however, he only harvested six gunia. He prioritized keeping all his maize to feed his family rather than repaying the Panther loan, and therefore defaulted on his loan of four gunia and was taken to court by Panther. Similarly, another farmer had recently sent her child away to boarding school and was required to provide enough maize upfront to feed him for the year. She defaulted on her Panther loan as her harvest was smaller than usual, meaning that she was unable to save enough maize to feed those living in her house, send money to her child's school, and repay the loan. Usually she would also give some maize away to poorer families and orphans, and pay offerings to the church, but in 2015 she was unable to do that as well.

In the context of smaller than average harvests farmers had to make important decisions about how to prioritize uses for their maize in order to meet household needs. Panther, however, continued to rigidly enforce loan repayment by set deadlines. The result was mass dissent against Panther Progress, which played out in the form of refusal to repay, writing of letters of complaint, appeals to village and local government, and lack of interest in continuing to participate in the programme. Major objections were related to perceived violations of moral economic norms of the farmers in two ways: material inflexibility and temporal inflexibility.

\section{Material inflexibility of Panther loans}

Panther was unwilling to allow farmers to substitute repayments in maize for repayments in money in 2015, and if they repaid in money they would not be considered for another loan in the future. This effectively shut down repayment options for farmers who wanted to retain all their maize to feed their family, but who were able to pay using capital raised from alternative livelihood sources. This material inflexibility was due to the reliance on maize repayments built into the Panther model. Panther aims to build a commercial market for maize, and in doing so makes a profit when the maize is sold on to the market buyer. Panther therefore loses out if farmers repay in money rather than in maize. For some farmers, however, repaying their loans in money made more sense than repayment in maize. The Panther model assumes that farmer livelihoods are based on a single injection of capital after the maize harvest that is often not substantial enough to create a surplus to sell. This presumption, however, does not match complex livelihood mosaics. 
There is evidence of a dynamic cash economy among farmers in Lower Kilolo: farmers are able to access cash much more often, and with more ease, than the Panther model seems to expect. Farmers often have nonagricultural incomes such as running a shop, making and selling maandazi (doughnuts), working as a watchman, or they can access capital through selling commercial crops, hiring out livestock or equipment, or working on the fields of other people for money. Furthermore, there are vibrant lending and borrowing relationships between farmers. There is much reciprocal borrowing between friends, family, and neighbours, especially during periods of high expenditure such as planting and weeding. These loans are often rotating over time, with borrowers becoming lenders, and lenders becoming borrowers. Due to the networks of trust engendered by the social and physical proximity of borrowers and lenders, these loans do often involve material flexibility, for example a loan that was intended to be repaid in sunflower could instead be repaid in labor, cash, or another crop. Panther's inflexible enforcement of repayment in maize in 2015 did not allow for these alternative pathways, and instead attempted to rigidly discipline farmers into prioritizing the commercial use-value of their maize.

\section{Temporal inflexibility of the Panther loans}

Another point of contradiction between the Panther model and participating farmers in 2015 that shut down alternative pathways and coping mechanisms was over temporal inflexibility. Panther attempted to enforce rigid repayment timetables due to pressure on the organisation to repay their own loans to the bank and to provide hope of a future return to their investors, as well as their desire for farmers to conform to the norms of standardized financial practices to become 'creditworthy' and 'investable.' This caused a problem in the context of smaller than average maize harvests in 2015. In the face of threats of the repossession of collateral if loans were not repaid, in Vitono a group of participating farmers wrote a letter to the Panther office describing the situation they faced. They asked if they could delay repayment to the following year and receive a loan of half the standard size to enable them to harvest a sufficient quantity to pay back their loans. Instead, Panther proceeded to take a few farmers to court in order to enforce repayment. Farmers in Vitono expressed the perceived injustice of this situation as "with Panther they wait until you harvest and then you have to pay whether you had enough harvest or not." Another farmer reported that:

It got to the point where Panther wanted to sue the farmers, but I had to talk to them to settle it down and ask for a time extension, but until now the farmers are still paying back the loans. It hurt the farmers emotionally as it showed Panther thought we weren't trustworthy. We had to write them a letter about the situation and asked to pay back their loans this season, but they have been collecting their money until now. The farmers were even asking if they can get at least half of the loan this year on top of the other one, but Panther didn't agree to give other loans in fear of failure to pay them back.

This controversy over temporal inflexibility highlights contradictions at the intersections of capitalism, agriculture, and time. For Panther, time and money are lineally related, with calculations like interest rates accounted for incrementally. In other words, time is money. Panther sees temporal inflexibility as equated with 'reliability' and of central importance to the alleviation of poverty: "economies come because capital can reliably go somewhere and into something. Until that is fixed there can't be a value chain built around them successfully because they are not reliable." In comparison, for farmers in Lower Kilolo the relationship between time and money is more fluid and dynamic, and often conceptualized in terms of seasonal tasks and agricultural production cycles. This is demonstrated by the practice of delaying farmer-to-farmer loan repayments due to recognition of poor harvests or individual hardship. This temporal flexibility is closely related to the social and physical proximity of farmer-to-farmer borrowers and lenders, in comparison to the more distanced and disciplining commercial loans based on rigid repayment timetables like that of Panther. Similar to material inflexibility, these rigid repayment schedules closed down alternative pathways and coping mechanisms. 


\section{Conclusions: clashes between a vision of ethical capitalism and farmers' moral economies}

This article demonstrates the continuing relevance of moral economy analyses for political ecologists in understanding socio-economic interactions in the agricultural sector. It enables us to go beyond focusing on conflicts over access to resources to understand how the values ascribed to those resources, as well as moral conceptions of justice over their use, shape winners and losers in development processes.

While in the earlier years of the Panther programme there were no major conflicts over the implementation of the model, after the low and variable rainfall and rat infestation of 2014-2015 a range of clashes were exposed between the ethical capitalism implemented by the organisation, and the moral economic principles of the farmers. These clashes were more than conflicts over access to resources. They were centred on the often-conflicting roles and values ascribed to maize, and the extent of socially sanctioned temporal and material flexibility in borrowing and lending transactions in the context of hardship induced by environmental disruptions. While for the farmers maize played key socio-cultural, nutritional, spiritual, and economic roles, Panther prioritized maize as a commodity for exchange. As a result, the organisation rigidly attempted to discipline farmers into repaying their loans in maize by set repayment schedules, regardless of the hardship that this would bring in the context of smaller than average harvests. This effectively shut down flexible alternative pathways and coping mechanisms, for example repayment in other forms or postponing repayment to the following harvest, that are often employed in farmer-to-farmer lending. The form of ethical capitalism implemented by Panther violated the moral economic principles of the farmers, leading to widespread outcry and a breakdown of relations between Panther and participating farmers. This breakdown in relations between Panther and participating farmers was so severe that no input loans were issued at all in Lower Kilolo in 2015, few farmers signed up for the programme in 2016, and by January 2018 Panther had closed down its business in Tanzania.

Taking a step back, this case study of Panther Progress's programme in Lower Kilolo in 2014-2015 demonstrates the challenge of implementing universalized assumptions of what constitutes 'ethical capitalism' and equating positive social impact with the imposition of Western financial norms. What can be considered a positive social impact for one may be experienced as increased hardship for another, and conceptions of positive social impacts are inherently context-specific and imbued with moral economic norms. The debate over agricultural development is not just about the role of private capital and how to harness it for positive social impact, but also concerns problematic assumptions and ideals about smallholder farmer livelihoods, their crops, and their moral economies in SSA. Political ecologists have an important role to play in unpacking these problematic assumptions and ideals to prevent SII producing more losers than winners.

\section{References}

Adams, W.M. 2003. Green development: environment and sustainability in the third world. London: Routledge.

Agrawal, A. 1995. Dismantling the divide between indigenous and scientific knowledge. Development and Change 26: 413-439.

Bisanda, S., W. Mwangi, H. Verkuijl, A.J. Moshi and P. Anandajayasekeram. 1998. Adoption of maize technologies in the Southern Highlands of Tanzania. Mexico: CIMMYT, United Republic of Tanzania, and SACCAR.

Booth, W.J. 1994. On the idea of the moral economy. American Political Science Review 88(3): 653-667.

Brest, P. and K. Born. 2013. When can impact investing create real impact? Stanford Social Innovation Review Fall.

Brooks, S. 2016. Inducing food insecurity: financialization and development in the post-2015 era. Third World Quarterly 37(5): 1-13.

Bugg-Levine, A. and J. Emerson. 2011. Impact investing: transforming how we make money while making a difference. Innovations: Technology, Governance, Globalization 6(3): 31-40. 
Chambers, R. 1983. Rural development - putting the last first. London: John Wiley.

Clapp, J. 2014. Financialization, distance, and global food politics. The Journal of Peasant Studies 41(5): 797814.

Clapp, J. 2012. The financialization of food: who is being fed? In International Society for Ecological Economics Conference. 12-16 June. Rio de Janeiro.

Conway, G. 1997. The doubly Green Revolution: food for all in the twenty-first century. New York: Comstock Publishing Associates.

Dodd, N. 2014. The social life of money. Princeton: Princeton University Press.

Edelman, M. 2005. Bringing the moral economy back in to the study of twenty first century transnational peasant movements. American Anthropologist 107(3): 331-345.

Ellis, F. 1993. Peasant economies farm households and agrarian development. Cambridge: Cambridge University Press.

Fairhead, J. and M. Leach. 1996. Misreading the African landscape. Cambridge: Cambridge University Press.

Fourcade, M., P. Steiner, W. Streeck and C. Woll. 2013. Moral categories in the financial crisis. MaxPo Discussion Paper 13/1. Paris: Max Planck Sciences Po Centre of Coping with Instability in Market Societies.

Ghosh, J. 2010. The unnatural coupling: food and global finance. Journal of Agrarian Change 10(1): 72-83.

Godfray, H.C., J.R. Beddington, I.R. Crute, L. Haddad, D. Lawrence, J.F. Muir, J. Pretty, S. Robinson, S.M. Thomas and C. Toulmin. 2010. Food security: the challenge of feeding 9 billion people. Science 327: 812-818.

Gotz, N. 2015. 'Moral economy': its conceptual history and analytical prospects. Journal of Global Ethics 11(2): 147-162.

Graeber, D. 2014. Debt: the first 5000 years. New York and London: Melville House Publishing.

Isakson, S.R. 2014. Food and finance: the financial transformation of agro-food supply chains. Journal of Peasant Studies 41(5): 749-775.

Leirs, H., R. Verhagen and W. Verheyen. 1990. The use of rainfall patterns in predicting population densities of multimammate rats, Mastomys natalensis. In Proceedings of the Fourteenth Vertebrate Pest Conference. Paper 53: 135-138.

Leirs, H., R. Verheyen and T. Mbise. 1996. Forecasting rodent outbreaks in Africa: an ecological basis for Mastomys control in Tanzania. Journal of Applied Ecology 33(5): 937-943.

Makundi, R., A. Bekele, H. Leirs, A.W. Massawe, W. Rwamugira and L.S. Mulungu. 2005. Farmers' perceptions of rodents as crop pests: knowledge, attitudes, and practices in rodent pest management in Tanzania and Ethiopia. Belgian Journal of Zoology 135: 153-157.

Makundi, R., A. Massawe and L. Mulungu. 2006. Ecological considerations for management of rodent pests in Tanzania. In R. Makundi (ed.). Management of selected crop pests in Tanzania. Dar es Salaam: Tanzania Publishing House. Pp. 224-239.

Massawe, A. L.S. Mulungu, R.H. Makundi, N. Dlamini, S.J. Eiseb, F. Kirsten, T. Mahlaba, P. Malebane, E. Von Maltitz, A. Monadjem, P. Taylor, V. Tutjavi and S.R. Belmain. 2011. Spatial and temporal population dynamics of rodents in three geographically different regions in Africa: implications for ecologically-based rodent management. African Zoology 46(2): 393-405.

Mazur, R. and S. Titilola. 1992. Social and economic dimensions of local knowledge systems in African sustainable agriculture. Sociologia Ruralis 32: 264-286.

Mboya, R., P. Tongoona, J. Derera, M. Mudhara and A. Langyintuo. 2011. The dietary importance of maize in Katumba Ward, Rungwe District, Tanzania, and its contribution to household food security. African Journal of Agricultural Research 6(11): 2617-2626.

Mortimore, M.J. 1998. Roots in the African dust: sustaining the Sub-Saharan drylands. Cambridge: Cambridge University Press. 
Netting, R. 1993. Smallholders, householders: farm families and the ecology of intensive, sustainable agriculture. Stanford: Stanford University Press.

O'Donohoe, N. C. Leijonhufvud, Y. Saltuk, A. Bugg-Levine and M. Brandenburg. 2010. Impact investments: an emerging asset class. morganmarkets.com.

Ogawa, S. 2006. "Earning amongst friends": business practices and creed among petty traders in Tanzania. African Studies Quarterly 9(1\&2): 23-38.

Ohna, I., R. Kaarhus and J. Kinabo. 2012. No meal with ugali? Social significance of food and consumption in a Tanzanian village. Culture, Agriculture, Food and Environment 34(1): 3-14.

Ouma, S. 2016. From financialization to operations of capital: historicizing and disentangling the financefarmland nexus. Geoforum 72: 82-93.

Peet, R. and M.J. Watts (eds.). 1996. Liberation ecologies: environment, development, and social movements. London: Routledge.

Richards, P. 1985. Indigenous agricultural revolution: ecology and food production in West Africa. London: Hutchinson.

Rocheleau, D.E., L. Ross, J. Morrobel, L. Malaret, R. Hernandez and T. Kominiak. 2001. Complex communities and emergent ecologies in the regional agroforest of Zambrana-Chacuey, Dominican Republic. Cultural Geographies 8(4): 465-292.

Roitman, J. 2003. Unsanctioned wealth; or, the productivity of debt in Northern Cameroon. Public Culture 15(2): 211-237.

Russi, L. 2013. Hungry capital: the financialization of food. Alresford: Zero Books.

Sarris, A. and J. Morrison. 2010. Food security in Africa: market and trade policy for staple foods in Eastern and Southern Africa. Cheltenham: Edward Elgar.

Sayer, A. 2000. Moral economy and political economy. Studies in Political Economy 61: 79-103.

Sayer, A. 2001. For a critical cultural political economy. Antipode 33(4): 687-708.

Scott, J. 1976. Moral economy of the peasant: rebellion and subsistence in Southeast Asia. Princeton: Princeton University Press.

Scott, J. 1987. Weapons of the weak: everyday forms of peasant resistance. New Haven: Yale University Press.

Scott, J. 1998. Seeing like a state: how certain schemes to improve the human condition have failed. New Haven: Yale University Press.

Sen, A. 1982. Poverty and famines: an essay on entitlement and deprivation. Oxford: Oxford University Press.

Shipton, P. 2010. Credit between cultures: farmers, financiers, and misunderstanding in Africa. New Haven: Yale University Press

Shiva, V. 1992. The violence of the Green Revolution: third world agriculture, ecology, and politics. New Delhi: Zed Press.

Sillitoe, P. (ed.) 2007. Local vs global science: approaches to indigenous knowledge in international development. New York: Berghahn.

Thompson, E.P. 1971. The moral economy of the English crowd in the eighteenth century. Past and Present 50: 76-136.

Watts, M.J. 1983. Silent violence: food, famine, and peasantry in Northern Nigeria. Berkeley: University of California Press.

Wolford, W. 2005. Agrarian moral economies and neoliberalism in Brazil: competing worldviews and the state in struggle for land. Environment and Planning A 37: 241-261. 